Växande småfolksfamiljers bostadsfråga belyst med några göteborgssiffror Author(s): K. A. Edin

Source: Ekonomisk Tidskrift, Årg. 17, häft 4 (1915), pp. 117-139

Published by: Wiley on behalf of The Scandinavian Journal of Economics

Stable URL: http://www.jstor.org/stable/3437476

Accessed: 27-06-2016 16:30 UTC

Your use of the JSTOR archive indicates your acceptance of the Terms \& Conditions of Use, available at

http://about.jstor.org/terms

JSTOR is a not-for-profit service that helps scholars, researchers, and students discover, use, and build upon a wide range of content in a trusted digital archive. We use information technology and tools to increase productivity and facilitate new forms of scholarship. For more information about JSTOR, please contact support@jstor.org.

Wiley, The Scandinavian Journal of Economics are collaborating with JSTOR to digitize, preserve and extend access to Ekonomisk Tidskrift 


\title{
Växande småfolksfamiljers bostadsfråga belyst med några göteborgssifffror.
}

\author{
Af K. A. Edin.
}

Det på grund af flere samverkande omständigheter alltjämt stegrade intresset för det komplex af sociala och ekonomiska spörsmål, som plägar sammanfattas under benämningen bostadsfrågan, har under den sista mansåldern gifvit upphof åt ett stort antal statistiska undersökningar. De två hufvudtyperna af de bostadssociala undersökningarna äro de allmänna, hela länder eller åtminstone ett större antal samhällen omfattande bostadsräkningarna och bostadsbeskrifningarna, ingående specialmonografier öfver något visst samhälles bostadsförhållanden, med uppmätning af rummens dimensioner, o. s. v. I båda dessa undersökningsformer har man flerstädes, så äfven på sista tiden i Sverige, till behandling upptagit hyrans förhållande till årsinkomsten för olika inkomstoch socialgrupper - den s. k. relativa bostadshyran, en beteckning som emellertid knappast kan anses vidare lyckad, då ju t. ex. hyran pr kubikmeter luftrymd med väl så stort fog kan göra anspråk därpå. I brist på bättre uttryck skall jag i denna uppsats använda beteckningen »hyresprocenten».

Onekligen hör studiet af hyrans förhållande till inkomsten till bostadsstatistikens allra intressantaste partier - men också till dess svåraste. Den statistik, som här skall demonstreras, betraktas också öfvervägande som illustrationsmaterial för belysande af det statistiska problemets vanskligheter.

Först några ord om de vid bostadsräkningarna utförda hyresprocentundersökningarna, närmare bestämdt socialstyrelsens vid de år I 9 I 2 igångsatta räkningarna, hvilka hittills resulterat i nio specialberättelser, hvar och en för sitt samhälle, den första utkommen I9I3, behandlande Vänersborg (4I sidor). Då de öfriga i allt hufvudsakligt följt Vänersborgsberättelsen som mönster, har jag inskränkt mina anmärkningar till den.

Ekonomisk Tidskrift. 1915. Häft. 3. 
Inkomstuppgifterna ha här hämtats direkt ur taxeringslängderna, ur hvilka antecknats »vederbörande bostadsinnehafvares och dennes familjemedlemmars till inkomst- och förmögenhetsskatt taxerade årsinkomst, om sådan förefinnes, men eljest - och sålunda i regel vid inkomster lägre än $800 \mathrm{kr}$. - taxeringen till bevillning för inkomst af kapital och arbete». Hyresbeloppen ha fåtts genom hyresvärdarnas eller ev. lägenhetsinnehafvarnas af hyresvärdarna kontrollerade skriftliga uppgifter å den utsända frågeblanketten. I undersökningen af hyrans förhållande till inkomsten ha endast sådana hushåll medtagits, » för hvilka hyresbeloppet anger, hvad som utgifvits för det direkta bostadsbehofvets tillfredsställande». Uteslutits ha sålunda dels s. k. »blandade lägenheter», hvilkas hyra jämväl innesluter vissa yrkesutöfningens driftkostnader såsom kontors-, butiks-, verkstads- o. d. lokaler, dels lägenheter med inhyrande. Vidare har man naturligen nödgats utskilja sådana hushåll, hvilkas årsinkomst antingen ej kunnat utrönas, emedan de ej kunnat identifieras $\mathrm{i}$ taxeringslängderna, eller där ingen medlem taxerats för inkomst (den förra af dessa båda grupper beräknas till ej mindre än tredjedelen af bådas sammanlagda summa, delvis beroende på att hyresuppgifterna afsett året 1912, men inkomstuppgifterna året I9II, den I9I 2 taxerade inkomsten). De för hyresprocentundersökningen disponibla hushållen ha till slut fördelats $\mathrm{i}$ ett stort antal inkomstgrupper (ej mindre än $\mathrm{I} 7$, från 500 till $\mathrm{IO}, \mathrm{OOO} \mathrm{kr}$. inkomst och däröfver), hvarje grupp ytterligare $\mathrm{i}$ tvenne, »a) om hänsyn tages endast till lägenhetsinnehafvarens inkomst, och b) om familjemedlemmarnas inkomster tilläggas», hvartill anmärkes, att »det kända förhållandet, att familjemedlemmar med egen inkomst blott pläga lämna en del däraf till det gemensamma hushållets utgifter, torde motvägas därigenom, att dylika biförtjänster på grund af lag och praxis mycket bristfälligt komma till synes $i$ taxeringslängderna». Hvar och en af dessa grupper har ytterligare, där så varit möjligt, uppdelats i tvenne, arbetarhushåll och »öfriga hushålls. Till slut har bildats en särskild grupp "mindre bemedlade hushåll», där hushållsföreståndarens inkomst understiger $2,000 \mathrm{kr}$, med 4 undergrupper: arbetare, lägre tjänstemän, själfständigare näringsidkare och pensionärer, understödstagare $\mathrm{m}$. fl. (den första undergruppen ytterligare fördelad i egentliga grofarbetare, ett par yrkesarbetargrupper och »öfriga», 
den tredje $\mathrm{i}$ handlande, handtverkare och »öfriga»). För alla dessa olika grupper har hyran uträknats i procent af inkomsten, dels $\mathrm{i}$ genomsnitt, dels i flere procentgrupper (ända till i I).

Socialstyrelsens undersökningar ha, såsom ju var all anledning att vänta, bekräftat flere gånger förut gjorda iakttagelser, att hyresprocenten $\mathrm{i}$ stort sedt sjunker med stigande inkomst och stiger med stigande socialstandard och oförändrad inkomst, men sjunker från lägre till högre socialgrupp betraktad som helhet. Med detta allmänna resultat är emellertid ej alltför mycket vunnet. I hvarje fall synes stor försiktighet böra iakttagas vid sammanställningen och tolkningen af de funna hyresprocenterna. När man t. ex. af Vänersborgsberättelsen finner, att ej mindre $14,8 \%$ af de söfriga hushållens» grupp, 29,3 \% af de själfständiga mindre bemedlade näringsidkarnas, $32,2 \%$ af pensionärernas betala minst $30 \%$ af sin inkomst i hyra (om endast lägenhetsinnehafvarens inkomst tages i betraktande; tilläggas familjemedlemmarnas, bli motsvarande procenttal 10,9 \%,24 \% och 21,4\%), måste man gå ut ifrån, att dessa grupper i ett eller annat afseende äro sabnorma", eller $\mathrm{i}$ hvarje fall att de icke äro jämförbara med de grupper, med hvilka man närmast velat jämföra dem, arbetare och lägre tjänstemän, med $2, x \%$ resp. $7,8 \%$ hushåll med minst $30 \%$ hyra af lägenhetsinnehafvarens inkomst. Att full jämförbarhet icke föreligger, har tydligen också föresväfvat Vänersborgsberättelsens författare att döma af följande yttrande: "Beträffande de mindre, själfständiga näringsidkarne skulle man visserligen vara böjd att tillskrifva den höga relativa hyran förhyrandet utaf affärshänsyn af en välbelägen, större lägenhet, men denna förklaringsgrund torde blott delvis vara riktig, då förevarande statistik endast afser egentliga bostadslägenheter, icke bostäder kombinerade med affärslokaler. Pensionärs- och understödstagargruppens ofta mycket höga hyresprocenter - - - torde i vissa fall förklaras genom förefintligheten af vissa, i taxeringslängderna ej redovisade inkomstkällor, såsom understöd af släktingar $\mathrm{m}$. m.»

Förklaringen till den utsträckta förekomsten af sabnorma s hyresprocenttal inom vissa jämförelsegrupper (utom de ofvan nämnda $\mathrm{i}$ allmänhet de allra lägsta inkomstgrupperna) torde till stor del vara att söka i ofullkomligheter hos materialet, framförallt naturligen hos inkomstuppgifterna, ofullkomligheter som nödvän- 
digtvis äro förbundna med den använda metoden för inkomstuppgifternas inhämtande, men som $\mathrm{i}$ någon mån kunnat göras mindre kännbara vid jämförelsen mellan de olika social- och inkomstgrupperna, om man kunnat uppdela dessa också efter hushållssammansättningen, efter lägenhetsinnehafvarens ålder och civilstånd, barnens antal och ålder o. s. v.

Hvad först taxeringsuppgifternas värde beträffar, så är det klart, att de med en helt olika grad af exakthet kunna anges för t. ex. en grofarbetare utan fast sysselsättning (säsongarbetare) och för fabriksarbetare, för hvilka de kunna hämtas ur arbetsgifvarens böcker, eller för en mindre, själfständig näringsidkare och för en mindre tjänsteman. I den mån uppgiften ej kan kontrolleras, tenderar den naturligen att bli för låg. Härtill kommer, att ju mindre mannen förtjänar till hushållet, eventuellt på grund af oordentligt lefnadssätt, såsom bland ett stort antal säsongarbetare, desto starkare blir pressen på hustrun att också bidraga till familjens underhåll, men de tillfälliga inkomster en arbetarhustru med barn kan intjäna, torde endast undantagsvis komma till synes $\mathrm{i}$ taxeringssiffrorna. Man har all anledning antaga, att dessa tilläggsinkomster - i enstaka fall lika stora som mannens eller t. o. $\mathrm{m}$. större -, som ytterst sällan kunna kontrolleras, äro proportionsvis störst inom de lägsta inkomst- och socialgrupperna.

I början af I9I I utförde jag på uppdrag af Göteborgs stadsfullmäktige en ingående »bostadsbeskrifning» omfattande något mer än 5,00o göteborgska småfolkshushåll med högst 2 rum och kök, hvarvid jag bl. a. ställde utförliga frågor rörande såväl inkomst- som familjeförhållanden. För föreliggande uppsats har jag verkställt en bearbetning af inkomst- och hyresuppgifterna för familjer utan inhyrande bestående af man, hustru och minst 2 hemmavarande barn under I 5 år. För tre distrikt ha inkomstuppgifterna, som innefatta äfven de minsta inkomster specificerade (mans, hustrus, barns, fattigunderstöd m. m.), verificerats med utdrag ur I9I I års taxeringslängder (I9IO års inkomst). Ehuruväl de på detta sätt vunna jämförelsetalen grundats på inalles endast i I6 hushåll, vill jag dock i detta sammanhang nämna, att deras sammanlagda inkomst enligt de å bostadskorten af undersökarna efter lägenhetsinnehafvarnas eller deras hustrurs uppgifter inskrifna summorna når obetydligt högre 
belopp än enligt taxeringsuppgifterna för samma hushåll, IO I,5\%. Fördelas hushållen $\mathrm{i}$ inkomstgrupper enligt taxeringsuppgifterna, visar det sig, att dessa $i$ stort sedt $i$ de lägsta inkomstgrupperna äro lägre än bostadskortens, men något högre i de högsta. Uppdelas de I 6 hushållen i 3 inkomstgrupper, under I,000 kr., I,O00-- I,300 kr. och I,300-1,600 kr., bli de IOI,5 \% motsvarande safvikningstalen I I 9,2 \% (23 hushåll), I 09 \% (35 hushåll) och 95 \% (58 hushåll).

Vågade man draga någon slutsats af dessa små tal, skulle den vara, att tendensen att deklarera för låg inkomst inom de omhandlade socialgrupperna är mest utpräglad inom de lägsta inkomstkategorierna. Då hustru- och barninkomster - åtminstone af de meddelade årsbeloppen att döma - för de I 6 hushållen spela en mycket underordnad roll, synes det anmärkta förhållandet endast $\mathrm{i}$ ringa, om ens $\mathrm{i}$ någon mån kunna förklaras med dessa tilläggsinkomsters större betydelse för de lägsta inkomstgrupperna. Vore de tre procenttalen $\mathrm{i}$ någon mån representativa, skulle man alltså ha anledning förmoda, att den med stigande inkomst (och socialstandard) sjunkande hyresprocentserien redan på grund af en viss tendens hos de lägsta inkomstgrupperna att undertaxera sin inkomst ter sig något mera utpräglad, än hvad fallet skulle vara, om ej denna tendens förefunnes. Särskildt har man grundad anledning antaga, att en hel del af de mycket höga hyresprocenterna blott äro pappersprocenter. Af de I I 6 hushållen uppvisa sålunda 20 minst $25 \%$ hyresprocent, däraf I 3 med afsevärdt lägre taxerad inkomst än den å bostadskortet uppgifna - af 6 med minst $30 \%$ hyresprocent kommer en enda upp till denna gräns enligt bostadskortet, af de I 3 komma endast 8 upp till $25 \%$ och däröfver. Enligt bostadskorten åter komma i 8 hushåll upp till $25 \%$ och däröfver. Antages den högre af de båda källornas inkomstuppgifter som den sannolikaste, få vi för samtliga I 6 hushåll en sammanlagd inkomst som med $7,7 \%$ öfverstiger den taxerade. För de tre ofvan nämnda inkomstgrupperna bli motsvarande procenttal $2 \mathrm{I}, \mathrm{x} \%$, I $3,5 \%$, och $2,3 \%$. Medelhyresprocenten sjunker på detta sätt för samtliga lägenheter från $19 \%$ till $17,6 \%$, för de fyra inkomstgrupperna under $\mathrm{I}, 000 \mathrm{kr}$., I,000-I,300, I,300-I,600 och. minst I,600 kr. från $25,8 \%, 2 \mathrm{I}, 4 \%, \mathrm{I} 8,7 \%$ och I 5,7 $\%$ till $2 \mathrm{I}, 3 \%, \mathrm{I} 8,8 \%, \mathrm{I} 8, \%$ och $15,2 \%$. 
Kvinnornas förvärfsarbete kan emellertid i någon ringa mån inverka störande på jämförbarheten mellan olika inkomstgrupper äfven ur hyrans synpunkt, i det fall nämligen då det medför ökade anspråk på bostadsutrymme, och hyran alltså faktiskt kommer att innesluta vissa driftkostnader, exempelvis för hemarbete af hvarjehanda slag, såsom sömnad och stickning, till på köpet kanske utan att den genom hemarbetet vunna inkomsten kommer till synes på inkomstsidan. I de fall då äfven barnen, kanske t. o. m. mannen, eventuellt också främmande arbetsbiträden, äro engagerade $\mathrm{i}$ hemarbetet, kan missförhållandet mellan hyra och taxerad inkomst bli synnerligen påfallande. Då socialstyrelsens bostadsräkningsformulär icke upptager någon rubrik för hemarbete, då lägenheter med arbetsbiträden ej äro utskilda från hyresprocentundersökningen, och då arbetslokal använd som bostadsrum ej kan ha afskiljts från den öfriga bostadslägenheten, kan förekomsten af hemarbete möjligen i någon mån förklara de höga hyresprocenterna för särskildt en del mindre, själfständiga näringsidkare. Måhända är det någon tanke ditåt, som föresväfvat Vänersborgsberättelsens författare vid affattningen af den något svårtydda, ofvan citerade anmärkningen beträffande dessa (»denna förklaringsgrund torde blott delvis vara riktig»).

Gäller det om hustrurnas inkomster, att deras i taxeringslängderna ej skönjbara förekomst kan inverka störande på jämförbarheten mellan olika grupper, så gäller detta $\mathrm{i}$ ännu långt högre grad om de äldre hemmavarande barnens, till en viss grad också om från hemmet bortflyttade barns och om öfriga släktingars underhållsbidrag. Det torde rent af kunna sättas i fråga, huruvida en utredning af bostadshyrans förhallande till inkomsten, vare siglägenhetsinnehafvarens eller hela hushallets, för familjer med vuxna barn - för att ej tala om änkehushåll och syskonhushåll - icke innesluter alltför många osäkra moment beträffande både inkomstens och hyrans beräkning för att ge resultat af värde. För min del tror jag, att man gör riktigast $\mathrm{i}$ att ur hyresprocentundersökningarnas synpunkt jämställa dylika hushåll med hushåll med inhyrande. Hvarken totalinkomst eller hyra kunna här betraktas som ekonomiska enheter. I den mån barnen, efter att i någon större utsträckning ha blifvit egna inkomsttagare, kvarstanna i hemmet, kommer deras inkomst att i allt mindre utsträckning stå till det gemensamma hushållets förfogande; de bli i själfva verket 
inhyrande. Sätter man nu dylika hushålls hela hyra $\mathrm{i}$ relation till husfaderns inkomst, får man en alldeles för hög hyresprocent, så mycket mer som åtminstone grofarbetarens inkomst vid den tid, då barnen börja kunna försörja sig, är stadd i tillbakagång. Sätter man den åter $\mathrm{i}$ relation till familjemedlemmarnas samlade inkomst, får man för låga hyresprocenter. När man vidare betänker, att barnens förvärfsarbete börjar olika tidigt inom olika socialgrupper, i allmänhet senare med stigande socialstandard, kommer man ovillkorligen till den slutsatsen, att hushåll med vuxna barn alldeles oafsedt de i hvarje särskildt fall uppgifna inkomst- och hyresförhållandena rättast icke böra sammanföras med familjer med endast yngre barn, där husfadern i alla normala fall ensam måste bära upp hushållets ekonomi. Vänersborgsberättelsens ofvan (sid. I I 8) citerade anmärkning, att det kända förhållandet, att familjemedlemmar med egen inkomst blott pläga lämna en del däraf till det gemensamma hushållets utgifter, torde motvägas därigenom, att dylika biförtjänster på grund af lag och praxis mycket bristfälligt komma till synes i taxeringslängderna ", rubbar icke denna slutsats' giltighet, så mycket mindre som dessa biförtjänster just $\mathrm{i}$ den mån, de komma till synes $\mathrm{i}$ taxeringslängderna, $\mathrm{i}$ aftagande utsträckning komma det gemensamma hushållet till godo.

Hålla vi oss $\mathrm{i}$ det följande endast till de unga familjerna, utan äldre barn, så kunna vi äfven här urskilja ett par »bostadssociala» utvecklingsskeden. Det första räcker från bosättningen, då mannen kan antagas vara mellan 25 och 30 år och hustrun ett par år yngre, tills ett par tre barn ha födts, den egentliga » familjebildningstiden». Därefter vidtager det andra, »familjeafslutningstiden », den $\mathrm{i}$ arbetarens lif mest kritiska perioden, under hvilken inkomsten $\mathrm{i}$ stort sedt står stilla, allt under det barnskaran ökas och därmed särskildt födans konto med naturnödvändighet fordrar allt större plats $\mathrm{i}$ budgeten. I och med detsamma, att det äldsta barnet börjat kunna själf bidraga till familjeunderhållet, börjar det värsta ekonomiska trycket att lätta, allra helst som vid denna tid familjetillväxten i regel är afslutad. Ju svårare detta tryck varit, desto tidigare måste barnen börja draga sitt strå till stacken. Om man alltså - såsom jag gjort - genomgående räknar den andra perioden vara slut, innan något hemmavarande barn fyllt I 5 år, får man taga i beräkning, att barninkomsterna i de lägsta inkomst- 
och socialgrupperna icke äro alldeles utan betydelse redan under detta skedes sista del, men sedan hastigt aftagande med stigande standard. I stort sedt kan dock denna åldersgräns anses vara för sin uppgift väl lämpad. Jämfördt med det första familjeskedet spelar det andras barninkomster i hvarje fall en viss roll för de lägre standardgrupperna, äfven om dessa små barninkomster naturligen endast i mycket ringa mån kunna statistiskt åtkommas. Hustruns inkomst däremot borde snarast spela en något mindre roll, särskildt om man går ut ifrån, att hon vid familjebildningens början kunnat utföra regelbundet utomhusarbete - dock är att märka, att bosättningen bland arbetarklassen i stor utsträckning äger rum, sedan ett barn redan födts eller fästekvinnan kommit $i$ grossess - och att barnsängarna äro talrika under den senare perioden, ett antagande som åter företrädesvis gäller de lägsta klasserna. Mannens inkomst torde, såsom redan antydt, för grofarbetaren kulminera innan den andra periodens slut. Hos de lägsta socialgrupperna komma understöd i en eller annan form säkerligen att spela en ej så liten roll under det andra familjeskedet, proportionsvis afgjordt större än under det första, äfven af det skälet att (bland grofarbetarklassens män) oordentlighet och superi då i högre grad hunnit komma till utveckling. I hvad mån de taxerade inkomsternas afvikningstal från de verkliga, om man med verklig inkomst menar summan af de influtna medel, med hvilka utgifterna bestridas, stiga eller sjunka från det första till det andra familjeskedet, torde vara nästan omöjligt att med någon säkerhet statistiskt utreda.

Hyrans förhållande till inkomsten för olika familjeskeden, olika barnantal, har gjorts till föremål för undersökning i ett flertal s. k. hushållsboksundersökningar. Dessa lida emellertid af det felet, att de endast kunna komma åt ett litet antal skötsamma elitarbetare och medelklassfamiljer. Vill man alltså t. ex. göra en studie endast öfver växande småfolksfamiljers bostadsfråga för ett enda samhälle - med enhetliga hyres- och inkomstförhållanden -, är man icke mycket betjänad med ett dylikt material. Så mycket ha dock dessa undersökningar visat, som att hyresprocenten tenderar att sjunka med ökadt barnantal.

De statistiska sammanställningarna sidd. I 26 och I 27 af hyra och luftrymd, bostadstid m. m. med inkomst och barnantal, äro gjorda på 
grundval af vid den ofvan omnämnda göteborgsundersökningen insamladt material. Min afsikt har närmast varit att belysa hyrans förhållande till inkomsten för familjer, hvilka på grund af sin sammansättning borde ekonomiskt så godt som uteslutande uppbäras af familjefadern. Jag har alltså velat afskilja alla ur hyressynpunkt abnorma hushåll, hushåll med inhyrande (eller arbetsbiträden, dock ej tjänare) eller äldre barn med egna inkomster, hvilka faktiskt ekonomiskt sedt äro att betrakta som ett slags inhyrande, änkehushåll och hushåll med hustruförsörjning, o. s. v. För att vinna en fast norm har jag endast medtagit hushåll bestående af man, hustru och minst 2 hemmavarande barn, alla under 15 år, där hyran icke uppgår till $25 \%$ eller däröfver af hela den å bostadskortet upptagna familjeinkomsten. Denna sista inskränkning ter sig onekligen något betänklig. Jag kan emellertid försvara den med, att jag vid detaljstudier af de särskilda fallen kommit till det resultatet, att dylika fall till allra största delen antingen härröra från för låg inkomstuppgift eller beteckna en tillfälligt abnorm ekonomisk situation, t. ex. arbetslöshet på grund af sjukdom, eller inhyrandes afflyttning, då det nuvarande hyresläget bestämts med hänsyn till ett tidigare inkomstläge eller med tanke på inhyrande. Dessa senare fall borde kanske teoretiskt riktigare ha medtagits i undersökningen som motvikt mot de motsatta fallen af uppåtstigande från tillfälliga nödlägen. Häremot kan anföras, att i nödlägesfallen hyran antingen icke betalas, eller betalas med tillhjälp af understöd $\mathrm{i}$ en eller annan form, eventuellt genom nödarbete af hustru och barn, hvilka inkomsttillskott sällan till sitt fulla belopp komma till synes å korten, hvarförutom naturligen en hel del fall med under $25 \%$ hyresprocent höra till de tillfälliga nödlägesfallen, med å kortet ej fullt uppgifven inkomst. Gifvetvis höra större delen af de på grund af $25 \%$-gränsens öfverskridande ur undersökningen uteslutna hushållen till de lägsta inkomstgrupperna. Men härom mera nedan. Hela antalet medtagna hushåll är 767. Af dessa ha 46 eller $6 \%$, uppgifvits åtnjuta specificerad biinkomst af hustru eller barn. Till jämförelse skall nämnas, att i Vänersborg I I,5 \% af samtliga $\mathrm{i}$ hyresprocentundersökningen medtagna hushåll voro sådana, „där äfven familjemedlemmar hafva taxerad inkomst».

Att barnlösa familjer och enbarnsfamiljer ej medtagits, har berott på, att jag därmed trott mig utesluta ett relativt stort antal 


\begin{tabular}{|c|c|c|c|c|c|c|c|c|c|c|c|c|c|c|}
\hline & \multirow{2}{*}{$\begin{array}{c}\text { Årsinkomst } \\
\text { och } \\
\text { barnantal }\end{array}$} & \multirow{2}{*}{ 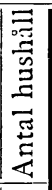 } & \multicolumn{2}{|c|}{$\begin{array}{c}\text { Årsinkomst } \\
\mathrm{kr} .\end{array}$} & \multicolumn{2}{|c|}{$\begin{array}{c}\text { Årshyra } \\
\text { kr. }\end{array}$} & \multirow{2}{*}{$\mid \begin{array}{c}\text { kol. } \\
5 \\
\text { io af } \\
\text { kol. } \\
3\end{array}$} & \multirow{2}{*}{ 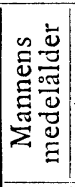 } & \multicolumn{2}{|c|}{$\begin{array}{c}\text { Hela } \\
\text { antalet } \\
\text { boende }\end{array}$} & \multicolumn{4}{|c|}{ Däraf barn om } \\
\hline & & & Summa & $\begin{array}{c}\text { Medel- } \\
\text { tal }\end{array}$ & $\underset{\text { mam- }}{\text { Sum }}$ & $\mid \begin{array}{c}\text { Medel- } \\
\text { tal }\end{array}$ & & & S:a & $\left|\begin{array}{c}\text { Me- } \\
\text { deltal }\end{array}\right|$ & $\stackrel{0-5}{a r}$ & $\underset{\mathbf{a r r}}{5-\mathbf{r o}}$ & $\left|\begin{array}{c}10-15 \\
\text { ar }\end{array}\right|$ & ${ }_{\text {ar }}^{0-15}$ \\
\hline & $\mathbf{I}$ & 2 & 3 & 4 & 5 & & 7 & 8 & 9 & IO & I I & 12 & 13 & I 4 \\
\hline $\mathbf{r}$ & Under $\mathrm{I}, 000 \mathrm{kr}$. ink. & 158 & 7,718 & 871,63 & 6,370 & 66,90 & 19,15 & 36,78 & 867 & 5,49 & 235 & 203 & 107 & 545 \\
\hline 2 & 2 barn ..... & 55 & 48, I 79 & 75,98 & 9,444 & I $7 \mathrm{I}, 7 \mathrm{I}$ & 19,60 & 34,76 & 22 I & 4,02 & 63 & 32 & 15 & I I \\
\hline 3 & $\cdot \cdot \cdot \cdot \cdot$ & $4 \mathrm{I}$ & 35,202 & $85^{8,58}$ & 6,846 & 166,98 & 19,45 & 35,80 & 206 & 5,02 & 62 & 46 & 15 & 123 \\
\hline 4 & $4, \ldots \ldots$ & $2 \mathrm{I}$ & 19,050 & 907,14 & 3,498 & 166,57 & 18,36 & 40,67 & 129 & $6, \mathbf{1 4}$ & 32 & 36 & 16 & 84 \\
\hline 5 & $5 \gg \cdot \cdot \cdot \cdots \cdot$ & 24 & 20,848 & 68,67 & $3,8 \mathrm{I} 6$ & I 59,00 & 18,30 & 37,92 & 169 & 7,04 & 42 & $5^{2}$ & 26 & 120 \\
\hline 6 & 6 och flere barn. & 17 & 14,439 & 849,35 & 2,766 & $162,7 \mathrm{I}$ & 19,16 & 39,24 & 142 & 8,35 & 36 & 37 & 35 & 108 \\
\hline 7 & $\mathrm{r}, 000-\mathrm{r}, 100 \mathrm{kr}$. & 137 & 142,410 & 039,49 & 26,670 & I 94,67 & I 8,73 & 34,75 & 722 & 5,27 & 204 & 160 & 79 & 443 \\
\hline 8 & 2 barn . . . . & $5^{2}$ & 54,056 & $\mathrm{I}, 039,54$ & 10,374 & $199,5^{0}$ & 19,19 & 32,12 & 2 I I & 4,06 & 68 & 28 & 8 & 104 \\
\hline 9 & $3 » \ldots .$. & $3^{8}$ & 39,3 I 2 & $\mathrm{I}, 034,53$ & 7,346 & 193,32 & I 8,69 & 35,53 & I9I & 5,03 & $6 I$ & 39 & I4 & I I 4 \\
\hline Io & $4 \gg \ldots . .$. & 22 & 22,89 I & 0,50 & $4, \mathrm{I} 44$ & I 88,36 & 18,10 & 36,45 & 132 & 6,00 & 26 & $4^{I}$ & $2 \mathbf{I}$ & 88 \\
\hline II & $5 》 \ldots . \cdots$ & I5 & 15,727 & $1,048,47$ & 2,952 & 196,80 & 18,77 & 36,67 & 106 & 7,07 & 28 & 30 & 17 & 75 \\
\hline 12 & 6 och flere barn. & Io & 10,424 & 42,40 & $\mathrm{I}, 854$ & 185,40 & $\mathbf{1 7 , 7 9}$ & 38,90 & 82 & 8,20 & $2 \mathrm{I}$ & 22 & 19 & 62 \\
\hline I3 & $1,100-1,300 \mathrm{kr}$. & 158 & I 87,606 & $, 187,38$ & 32,416 & 205,16 & 17,28 & 35,64 & 826 & 5,23 & 230 & I 84 & 90 & 504 \\
\hline 14 & 2 barn ..... & 64 & 75,972 & $\mathrm{I}, \mathrm{I} 87,06$ & I3,896 & 217,13 & 18,29 & 34,30 & $25^{8}$ & 4,03 & 82 & 34 & 12 & 128 \\
\hline I 5 & $3 " \cdots \cdot \cdot \cdot$ & 46 & 54,691 & I , I 88,93 & 9,340 & 203,04 & 17,08 & $34,4 \mathrm{I}$ & 233 & 5,07 & 68 & 54 & I6 & I 38 \\
\hline I6 & $4 » . . . \cdot$ & 24 & 28,474 & $\mathrm{I}, \mathrm{I} 86,42$ & 4,662 & $\mathrm{I} 94,25$ & 16,37 & $37,7 x$ & I 44 & 6,00 & 35 & 42 & 19 & 96 \\
\hline I7 & $5 \gg \ldots .$. & 9 & $10,73 \mathrm{I}$ & & 1,824 & 202,67 & 17,00 & 40,67 & 63 & 7,00 & 14 & I8 & I3 & 45 \\
\hline I8 & 6 och flere barn & 15 & 17,738 & $\mathrm{I}, \mathrm{I} 82,53$ & 2,694 & 179,60 & 15,19 & 38.80 & 128 & 8,53 & $3 I$ & 36 & 30 & 97 \\
\hline I9 & $\mathrm{I}, 300-\mathrm{r}, 600 \mathrm{kr}$. & 174 & 44,782 & ,406,79 & 37,048 & I 2,92 & I $5, \mathrm{I}_{4}$ & 35,94 & 904 & 5,20 & 238 & 192 & II 4 & 544 \\
\hline 20 & 2 barn . . . . & 66 & $92,27 I$ & $\mathrm{I}, 398,05$ & $\mathrm{I} 3,822$ & 209,42 & 14,98 & $33,6_{4}$ & 269 & 4,08 & 84 & 33 & I5 & I32 \\
\hline $2 \mathrm{I}$ & $3 » . . . \cdots$ & 53 & 75,031 & $\mathrm{I}, 4 \mathrm{I} 5,68$ & I I ,600 & 2 I 8,87 & I 5,46 & 35,00 & 268 & 5,06 & 75 & 57 & 27 & 159 \\
\hline 22 & $" \cdot \cdot \cdot \cdot$ & 34 & $48,08 \mathrm{I}$ & $\mathrm{I}, 4 \mathrm{I} 4, \mathrm{I5}$ & 7,286 & 214,29 & $\mathrm{I} 5, \mathrm{I} 5$ & 39,82 & 205 & 6,03 & 49 & 55 & 32 & I 36 \\
\hline 23 & $" \cdot \cdot \cdot \cdot \cdot$ & Io & I 3,399 & $1,339,90$ & 2,006 & 200,60 & 14,97 & 38,30 & 72 & 7,20 & I6 & 20 & I4 & 50 \\
\hline 24 & 6 och flere barn. & II & & $\mathrm{I}, 454,55$ & 2,334 & 212,18 & $\mathbf{I} 4,59$ & 40,18 & 90 & 8,18 & 14 & 27 & 26 & 67 \\
\hline 25 & r,60o kr.o. däröfver & 140 & 283,448 & $2,024,63$ & 40,728 & $290,9 \mathrm{I}$ & 14,37 & 36,99 & 744 & $5,3 \mathrm{I}$ & 188 & I59 & 94 & $44 I$ \\
\hline 26 & 2 barn . . . . & 53 & 104,836 & $\mathrm{I}, 978,03$ & 15,826 & 298,60 & $15, \mathrm{xo}$ & 34,75 & 217 & 4,09 & 62 & 27 & 17 & 206 \\
\hline 27 & $3 »$. & 47 & IOI,31 8 & $2, \mathrm{I} 55,7 \mathrm{c}$ & I 4,206 & 302,26 & 14,02 & 37,02 & 243 & 5,17 & 62 & 57 & 22 & I $4 \mathrm{I}$ \\
\hline 28 & $4 » \cdot \cdots \cdot$ & I8 & 34,953 & & 4,724 & 262,44 & 13,52 & 40,50 & I I 4 & 6,33 & 22 & $3 I$ & I9 & 72 \\
\hline 29 & $5 \gg . \cdots \cdot$ & I3 & 25,012 & $\mathrm{I}, 924,02$ & $3,7 \pm 2$ & 285,54 & 14,84 & 38,00 & 93 & 7,15 & 25 & 24 & I6 & 65 \\
\hline 30 & 6 och flere barn & 9 & 17,329 & $1,925,44$ & 2,260 & $25 \mathrm{I}, \mathrm{II}$ & I3.04 & 41,56 & 77 & 8,56 & 17 & 20 & 20 & 57 \\
\hline $3 I$ & Samtl.ink.-grupper & 767 & 995,964 & $\mathbf{I}, \mathbf{2 9 8 , 5 2}$ & 163,232 & 212,82 & 16,39 & 36,03 & 4,063 & 5,30 & I,095 & 898 & 484 & 2,477 \\
\hline 32 & 2 barn. & 290 & $375,3 \mathrm{I} 4$ & $1,294, x 9$ & 63,362 & 218,49 & 16,88 & 33,93 & 1,176 & 4,06 & 359 & I 54 & 67 & 580 \\
\hline 33 & 3 & 225 & 305,554 & $\mathrm{I}, 35^{8,02}$ & 49,338 & $2 \mathrm{I} 9,28$ & 16,15 & 35,54 & $\mathrm{I}, \mathrm{I} 4 \mathrm{I}$ & 5,07 & 328 & 253 & 94 & 675 \\
\hline 34 & $\cdot \cdot \cdot$ & II & I 53,449 & $I, 289,4^{8}$ & 24,314 & 204,32 & I 5,85 & 39,03 & 724 & 6,08 & 164 & 205 & 107 & 476 \\
\hline 35 & $» \cdot \cdot \cdot \cdot \cdot$ & $7 \mathrm{I}$ & 85,717 & $1,207,28$ & 14,3 IO & 201,55 & I 6,69 & 38,07 & 503 & 7,08 & 125 & I 44 & 86 & 355 \\
\hline 36 & 6 och flere barn. & 62 & 75,930 & $\mathrm{I}, 224,68$ & I I, 908 & 192,06 & \begin{tabular}{|l}
15,68 \\
\end{tabular} & 39,58 & 519 & 8,37 & II9 & 142 & 130 & $39 \mathrm{I}$ \\
\hline
\end{tabular}




\begin{tabular}{|c|c|c|c|c|c|c|c|c|c|c|c|c|c|c|c|}
\hline \multicolumn{3}{|c|}{$\begin{array}{l}\text { Barnens för- } \\
\text { delning i \% }\end{array}$} & \multirow{2}{*}{ 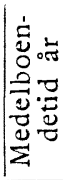 } & \multicolumn{2}{|c|}{ Antal rum } & \multicolumn{2}{|c|}{$\begin{array}{l}\text { Antal förut } \\
\text { bebodda rum }\end{array}$} & \multirow{2}{*}{$\left|\begin{array}{c}\text { kol. I } \\
\text { i } \% \\
\text { af } \\
\text { kol. } 2 \text { I }\end{array}\right|$} & \multicolumn{4}{|c|}{ Luftrymd $\mathrm{m} .^{3}$} & \multicolumn{2}{|c|}{$\begin{array}{c}\text { Årshyra } \\
\text { kr. }\end{array}$} & \\
\hline$\stackrel{0-5}{a r}$ & $5 \underset{\text { ár }}{5-10}$ & $\underset{\substack{\text { ar } \\
\text { ar }}}{25}$ & & $\begin{array}{c}\text { Sum- } \\
\mathrm{ma}^{1}\end{array}$ & $\begin{array}{c}\text { Medel } \\
\text { tal }\end{array}$ & Summa & $\begin{array}{c}\text { Medel- } \\
\text { tal }\end{array}$ & & Summa & $\left|\begin{array}{c}\text { pr lä- } \\
\text { genhet }\end{array}\right|$ & $\begin{array}{c}\text { pr } \\
\text { rum }\end{array}$ & $\begin{array}{c}\mathrm{pr} \\
\text { person- } \\
\text { enhet }\end{array} \mid$ & $\underset{\text { rum }}{\mathrm{pr}}$ & $\underset{\mathrm{m} .}{\mathrm{pr}}$ & \\
\hline I5 & I6 & I 7 & I 8 & I9 & 20 & $2 \mathrm{I}$ & 22 & 23 & 24 & 25 & 26 & 27 & 28 & 29 & \\
\hline $43, \mathbf{1 2}$ & 37,25 & 19,63 & 3,29 & $3 I 4,5$ & $\mathrm{I}, 99$ & $304, \circ$ & 1,92 & $\mathrm{I} 03,45$ & I I, 9 I $9,2 \mathrm{I}$ & 75,44 & 37,90 & 20,05 & 83,85 & $2,2 \mathrm{I}$ & I \\
\hline 57,27 & 29,09 & 13,64 & 3,06 & I IO, 5 & 2, or & IO2 & $\mathrm{I}, 85$ & 108,33 & $4,140,3^{8}$ & 75,28 & 37,47 & 24,94 & 85,47 & 2,28 & 2 \\
\hline $50,4 \mathrm{r}$ & 37,40 & 12,20 & 3,07 & 80 & $\mathrm{I}, 95$ & 76,5 & $\mathrm{I}, 87$ & I0 4,58 & $3, \mathrm{I} 69,42$ & 77,30 & 39,62 & $2 \mathrm{I}, 93$ & 85,58 & 2,16 & 3 \\
\hline 38,10 & 42,86 & 19,05 & 3,66 & 43 & 2,05 & 44 & 2,10 & 97,73 & $\mathrm{I}, 585,45$ & 75,50 & 36,87 & I 8,22 & $8 \mathrm{I}, 35$ & $2,2 \mathrm{I}$ & 4 \\
\hline $35, \infty 0$ & 43,33 & 21,67 & 3,82 & 48 & 2,00 & 47,5 & 1,98 & IOI, 05 & $\mathrm{I}, 792,28$ & 74,68 & 37,34 & 16,44 & 79,50 & $2, \mathrm{r} 3$ & 5 \\
\hline 33,33 & 34,26 & $32,4 \mathrm{I}$ & 3,39 & 33 & $\mathrm{I}, 94$ & 34 & 2,00 & 97,06 & $\mathrm{I}, 23 \mathrm{I}, 68$ & 72,45 & 37,32 & $\mathrm{I} 4,00$ & 83,82 & 2,25 & 6 \\
\hline 46,05 & $\mid 36,12$ & $|17,83|$ & 3, or & 278 & 2,03 & 271,5 & $\mathrm{I}, 98$ & $\mathrm{IO} 2,39$ & I I, 7 I 2,43 & 85,49 & $42,1_{3}$ & $23,4^{\circ}$ & 95,94 & 2,28 & 7 \\
\hline $65,3^{8}$ & 26,92 & 7,69 & 2,58 & 105 & 2,02 & 97 & $\mathrm{I}, 87$ & 108,25 & $4,387,84$ & 84,38 & $4 \mathrm{I}, 79$ & 27,60 & 98,80 & 2,36 & 8 \\
\hline $53,5 \mathrm{I}$ & 34,21 & 12,28 & 3,20 & 78 & 2,05 & 75 & $\mathrm{I}, 97$ & 104,00 & $3,356,20$ & 88,32 & 43,03 & 25,05 & $94, \mathrm{I} 8$ & $2, \mathrm{I} 9$ & 9 \\
\hline 29,55 & 46,59 & 23,86 & 2,85 & 45 & 2,05 & 49 & 2,23 & $9 \mathbf{I}, 8_{4}$ & $\mathrm{I}, 8 \mathrm{I} 2,2 \mathrm{r}$ & 82,37 & 40,27 & 20,59 & 92,09 & 2,29 & 10 \\
\hline 37,33 & 40,00 & 22,67 & 2,99 & 30 & 2,00 & 30 & $2, \infty 0$ & 100,00 & $\mathrm{I}, 287, \mathrm{I} 7$ & $85,8 \mathrm{r}$ & $4^{2,9 r}$ & I 8,79 & $98,4^{\circ}$ & 2,29 & II \\
\hline 33,87 & $35,4^{8}$ & 30,65 & 4,89 & 20 & 2,00 & 20,5 & 2,05 & 97,56 & 869, or & 86,90 & 43,45 & 17,04 & 92,70 & 2,13 & 12 \\
\hline 45,63 & $36,5 \mathrm{r}$ & $|17,86|$ & 3,55 & 323 & 2,04 & $22 \mathrm{I}$ & 2,03 & 100,62 & $14,074,15$ & 89,08 & 43,57 & 24,52 & 100,36 & 2,30 & I3 \\
\hline 64,06 & 26,56 & $9,3^{8}$ & 2,93 & 132 & 2,06 & 132 & 2,06 & 100,00 & $5,795,79$ & 90,56 & $43,9 \mathrm{r}$ & 29,88 & 105,27 & $2,4^{\circ}$ & 14 \\
\hline 49,28 & $39, \mathbf{r}_{3}$ & I I, 59 & 3,44 & 94 & 2,04 & 94 & 2,04 & 100,00 & $4,037,17$ & 87,76 & 42,95 & 24,62 & 99,36 & $2,3 \mathrm{I}$ & 15 \\
\hline 36,46 & 43,75 & 19,79 & 3,67 & 49 & 2,04 & 49 & 2,04 & 100,00 & $2,180,57$ & 90,86 & 44,50 & $22,7 \mathrm{I}$ & $95, \mathrm{I}_{4}$ & $2, \mathrm{I}_{4}$ & 16 \\
\hline $3 \mathrm{I}, \mathrm{Ir}$ & 40,00 & 28,89 & 6,59 & I 8 & $2, \infty 0$ & I 5 & $\mathbf{I}, 67$ & 120,00 & $828, \mathbf{1 2}$ & 92, or & 46, or & 20,45 & IOI,33 & 2,20 & 17 \\
\hline 31,96 & $37, \mathrm{II}$ & 30,93 & 4,49 & 30 & 2,00 & $3 \mathrm{I}$ & 2,07 & 96,77 & $\mathrm{I}, 232,5 \circ$ & 82,17 & $4 I, 08$ & I 5,50 & 89,80 & 2,19 & 18 \\
\hline 43,75 & 35,29 & 20,96 & 3,72 & 360 & 2,07 & 356 & 2,05 & 101,12 & $\mathrm{I} 6,129,12$ & 92,70 & 44,80 & 25,52 & $102,9 \mathrm{I}$ & 2,30 & 19 \\
\hline 63,64 & 25,00 & 11,36 & 3,00 & I 33 & 2,02 & 133 & 2,02 & 100,00 & $6,180,37$ & 93,64 & $4^{6,47}$ & 30,45 & $\mathrm{IO} 3,92$ & 2,24 & 20 \\
\hline $47, \mathrm{xy}$ & 35,85 & I6,98 & 3,27 & I 12 & $2, \mathrm{II}$ & 109 & 2,06 & 102,75 & $4,986,16$ & 94,08 & 44,52 & 26,45 & I03,57 & 2,33 & $2 \mathrm{I}$ \\
\hline 36,03 & 40,44 & 23,53 & $4,7 \mathrm{I}$ & 70 & 2,06 & 70 & 2,06 & 100,00 & $2,973,59$ & 87,46 & $4^{2}, 4^{8}$ & $2 \mathrm{I}, 7 \mathrm{r}$ & 104,09 & 2,45 & 22 \\
\hline 32,00 & $40, \infty$ & 28,00 & 5,73 & $2 \mathrm{I}$ & 2,10 & I9 & $I, 90$ & I I 0,53 & 960,17 & 96,02 & 45,72 & 20,43 & 95,52 & 2,09 & 23 \\
\hline 20,90 & 40,30 & $38,8 \mathrm{r}$ & 5,33 & 24 & 2,18 & 25 & 2,27 & 96,00 & $\mathbf{I}, 028,83$ & 93,53 & 42,87 & $18,2 \mathrm{I}$ & 97,25 & 2,27 & 24 \\
\hline $4^{2,63}$ & 36,05 & 21,32 & 3,87 & 344 & $2,4^{6}$ & 317 & 2,26 & 108,52 & I 7,455, , I & $\mathbf{1 2 4 , 6 8}$ & 50,74 & 33,34 & I 18,40 & 2,33 & 25 \\
\hline $5^{8,49}$ & 25,47 & 16,04 & 3,02 & I3 I & 2,47 & I I9 & 2,25 & I 10,08 & $6,647,8_{3}$ & I 25,43 & 50,75 & 40,54 & $\mathrm{I} 2 \mathrm{O}, 8 \mathrm{r}$ & 2,38 & 26 \\
\hline 43,97 & 40,43 & $I_{5}, 60$ & 4,03 & II 9 & 2,53 & 106 & 2,26 & I 12,26 & $6, \mathrm{OOI}, 43$ & I 27,69 & 50,43 & 34,79 & I I 9,38 & 2,37 & 27 \\
\hline 30,56 & 43,06 & 26,39 & 5,95 & $4 \mathrm{I}$ & 2.28 & 42 & 2,33 & 97,62 & $2,096,16$ & I I 6,45 & $5^{\mathrm{I}, \mathrm{r} 3}$ & 26,87 & I 15,22 & 2,25 & 28 \\
\hline 38,46 & $3^{6,92}$ & 24,62 & 3,97 & 32 & 2,46 & 30 & $2,3 \mathrm{I}$ & 106,67 & $1,716,24$ & $\mathrm{I} 32,02$ & 53,63 & 28,37 & I I $6, \infty$ & $2, \mathrm{r} 6$ & 29 \\
\hline 29,82 & 35.09 & 35,09 & 3,82 & $2 \mathrm{I}$ & 2,33 & 20 & 2,22 & 105.00 & 993.35 & I 10,37 & 47,30 & $20,4^{8}$ & 107,62 & 2,28 & 30 \\
\hline $44,2 \mathrm{I}$ & 36,25 & I 9,54 & 3,50 & $\mathrm{I}, 6 \mathrm{I} 9,5$ & $2, \mathrm{Ir}$ & $I, 569,5$ & 2,05 & 103,19 & $71,289,92$ & 92,95 & 44,02 & 25,24 & IOO,79 & 2,29 & $3 I$ \\
\hline $6 \mathrm{r}, 90$ & 26,55 & II 1,55 & 2,92 & $6 \mathrm{II}, 5$ & $2, \mathrm{II}$ & $5^{83}$ & 2, or & 104,89 & $27,15^{2,21}$ & 93,63 & $44,4^{\circ}$ & 30,65 & 103,62 & 2,33 & 32 \\
\hline 48,59 & $37,4^{8}$ & $\mathrm{I} 3,93$ & $3,4 \mathrm{r}$ & 483 & 2,15 & 460,5 & 2,05 & IO 4,89 & $21,55^{0}, 38$ & 95,78 & 44,62 & 26,82 & 102,15 & 2,29 & 33 \\
\hline 34,45 & 43,07 & 22,48 & $4, \mathbf{2 6}$ & 248 & 2,08 & 254 & $2, \mathrm{r}_{3}$ & 97,64 & $10,647,98$ & 89,48 & $4^{2}, 94$ & $2 \mathrm{I}, 9 \mathrm{I}$ & 98,04 & 2,28 & 34 \\
\hline $35,2 \mathrm{r}$ & 40,56 & 24,23 & 4,29 & I 49 & 2,10 & I $4 \mathrm{I}, 5$ & I, 99 & 105,30 & $6,5^{8} 3,98$ & 92,73 & $44, \mathrm{r} 9$ & 20,23 & 96,04 & 2,17 & 35 \\
\hline 30,13 & 36,32 & 33.25 & $4,3 \mathrm{r}$ & I 28 & 2,06 & I 30,5 & 2,10 & 98,08 & $5 \cdot 355 \cdot 37$ & 86,38 & $4 \mathrm{I}, 8_{4}$ & 16,55 & 93,03 & 2,22 & 36 \\
\hline
\end{tabular}

1 Rum med del i kök $=I^{1} / 2$ rum. 
hushåll med hustruinkomster eller med provisoriska bosättningar och höga hyresprocenter. Måhända hade det varit mera rationellt att i stället draga skiljegränsen vid en viss äktenskapsvaraktighet, t. ex. vid 15 år gamla äktenskap, eller vid en viss ålder hos hustrun, t. ex. 45 år, fruktsamhetsperiodens slut (inalles ett 50 -tal fall med hustrur om minst 45 år ingå bland de 767), eller hos mannen, t. ex. den ungefärliga inkomstkulmengränsen. Äfven mot dessa gränsbestämningar kunna dock befogade invändningar resas.

Då jag betecknat de 767 familjerna som »växande», har jag trott mig därmed tydliggöra, att hvad jag velat skildra är »normalfamiljens» ur bostadsfrågans, ur hemmets och ur samhällets synpunkt viktigaste och mest kritiska tidsskede, barnens första uppväxttid, innan de kunna ekonomiskt verksamt bispringa föräldrarna, i hufvudsak alltså den *andra perioden», enligt ofvan använd terminologi.

Efter barnantalet ha de 767 hushållen uppdelats i 5 grupper, med 2, 3, 4, 5 resp. 6 och flere barn, efter familjeinkomsten i likaledes 5 grupper, med I,000, I, IOO, I,300 och I,600 kr. som gruppgränser, valda så att grupperna äro någorlunda jämnstora, lägst I 37, högst I 74 hushåll. Observeras må dock, att om andra och tredje inkomstgruppen sammanslås, blir gruppintervallen äfven här $300 \mathrm{kr}$. Kombineras barnantal och inkomst, får man 25 grupper.

Hela den samlade årsinkomsten för I 9 IO uppgår för de 767 hushållen till nära 996,000 kr. eller I,299 kr. pr hushåll, årshyran till något mer än $\mathrm{I} 63,000 \mathrm{kr}$. eller $2 \mathrm{I} 3 \mathrm{kr}$. pr hushåll, i procent af inkomsten alltså $16,39 \%$. Jag kan i detta sammanhang icke underlåta att nämna, att jag ur den af Stockholms stads statistiska kontor utförda Statistisk undersökning angående lefnadskostnaderna i Stockholm àren 1907108 (Stockholm I9IO) af dess inalles I 50 hushåll till jämförelse uttagit dem, som uppfylla de af mig på de 767 göteborgshushållen uppställda fordringarna, med det undantag dock att ingen hyresprocentgräns uppdragits. Inalles fick jag på detta sätt endast 34 hushåll. Deras medelhyresprocent blef $16,3^{\mathrm{x}} \%$, alltså nära nog densamma som för de 767 göteborgshushållen, ehuru både medelinkomst och medelhyra i Stockholm voro afsevärdt högre. Ett enda af de 34 Stockholmshushållen uppvisar minst $25 \%$ hyresprocent $(26,4 \%)$. Inkomsten 
är här I,700 kr., men utgifterna öfverstiga den med $457 \mathrm{kr}$. Af 2 I familjer med endast I barn under 15 år däremot befunnos 3 betala en hyra, som med minst $25 \%$ öfverstiger inkomsten, i ett fall t. o. m. öfver $30 \%$; $\mathrm{i}$ alla tre öfverstiger den samlade utgiftssumman inkomstsumman, alla tre ha åtnjutit understöd, en hustruinkomst. Af alla de 55 stockholmshushållen $(34+2 \mathrm{I})$ uppvisa I 7 minst $20 \%$ hyresprocent, af dessa uppvisa I 2 inkomstunderskott (4 med minst io \% af hela inkomsten) - mot i 5 af de 38 öfriga.

Med stigande inkomst sjunker hyresprocenten både för göteborgs- och för stockholmshushållen. För de förra äro hyresprocenterna för de fem inkomstgrupperna I9,2 \%, I $8,7 \%$, I 7,3 \%, I 5, r $\%$ och $14,4 \%$. Fördelas de 55 stockholmshushållen $\mathrm{i}$ tre ungefär jämnstora grupper, under $\mathrm{I}, 800 \mathrm{kr}$., I,800/2,000 kr. och minst $2,000 \mathrm{kr}$. inkomst, bli hyresprocenterna $19, \mathrm{x} \%, 18,6 \%$ och $\mathrm{I}_{5,2} \%$; för samtliga sammanslagna $17,3 \%$. Med stigande barnantal får man också 'en sjunkande serie, åtminstone t. o. m. 4:de barnet: för de fem göteborgska barngrupperna: I6,9 \%, 16,2 \%, I 5,9\%, I $6,7 \%$ och I $5,7 \%$; sammanslås de båda sista, får man I6,2 \%. För I, 2, 3, 4 resp. 5 barn bli de stockholmska procenttalen I9,r \%, I 7,3 \%, I6,2 \%, I 4,5\% och I6,8\%; för de båda sista grupperna sammanslagna $\mathrm{I} 5,3 \%$ (de 5 stockholmsgrupperna räkna endast $2 \mathrm{I}$, I 5,5 , Io och 4 hushåll). Öfverensstämmelsen mellan hyresprocenttalen för resp. barngrupper måste, särskildt $\mathrm{i}$ betraktande af de absoluta talens litenhet, sägas vara öfverraskande god. För Stockholmsundersökningens samtliga I 50 hushåll befanns hyrans andel af totalutgiften för de fyra utgiftsgrupperna I, 200/I,750 kr., I,750/2,000 kr., 2,000/2,500 kr. och 2,500/5,000 kr. vara I9,8\%, I9,6\%, I $9 \%$ och I $8,4 \%$, för samtliga I 50 I $9 \%{ }^{1}$ För olika persontalsgrupper ha hyresprocenterna ej uträknats. I Göteborg stiger medelårshyran pr lägenhet något från 2- till 3-barnsfamiljerna, från $218,49 \mathrm{kr}$., till $219,28 \mathrm{kr}$., men sjunker sedan hastigt i nästa grupp till 204,32 kr., och ytterligare $\mathrm{i}$ de två följande, $20 \mathrm{I}, 55 \mathrm{kr}$. och 192,06 kr. Af de 55 stockholmsfamiljerna uppvisa tvåbarnsfamil-

1 I hyran ha här inräknats alla utgifter för bostaden, sålunda reparationer och flyttningskostnader o. d. Dessa småutgifter spela dock en ganska obetydlig roll. Medelhyran utgör för de 150 hushållen $407 \mathrm{kr}$., de öfriga bostadsutgifterna representera ett tillägg om $8 \mathrm{kr}$ 
jerna högre medelhyror än I-barnsfamiljerna och dessa i sin ord ning än 4- och 5-barnsfamiljerna (räknadt från I-barnsfamiljerna uppåt bli talen $350,57 \mathrm{kr}$., 377,27 kr., 323,oo kr. och 317,43 kr.). Medelinkomsten pr hushåll är i Göteborg störst för 3-barnsfamiljerna, i Stockholm för 2-barnsfamiljerna. (Den abnormt låga medelinkomsten för de göteborgska 5-barnsfamiljerna torde stå i samband med de absoluta talens litenhet; häraf förklaras då också den höga hyresprocenten.)

De å bostadskorten med bestämda belopp uppgifna tilläggsinkomsterna (hustrus, barns, understöd o. s. v.) uppgå för samtliga 767 hushåll till mindre än $\mathrm{I} 4,000 \mathrm{kr}$. eller ungefär $20 \mathrm{kr}$. pr hushåll, d. v. s. till $\mathrm{I}, 5_{5} \%$ af hela familjeinkomsten; i Stockholm uppgår den för de 34 2- t. o. m. 5-barnsfamiljerna till drygt $5 \%$, för I-barnsfamiljerna till något mer än $4 \%$, hvarvid dock är att ihågkomma, att alla bïnkomster här skulle uppges på öret. Några bestämda variationstendenser med stigande inkomst resp. barnantal har jag icke kunnat utleta för mina göteborgsfamiljer, naturligt nog bl. a. också af det skälet, att de olika tilläggsinkomsterna variera $\mathrm{i}$ olika riktningar. Af de $\mathrm{i} 58$ hushållen med under I, ooo kr. inkomst åtnjöto 8 eller $5 \%$ å bostadskortet preciserad hustruinkomst, inalles $\mathrm{I}, 530 \mathrm{kr}$. (i ett fall 780 kr. af en bageriarbeterska, hvars man på skomakeriarbete i hemmet uppgifvit sig förtjäna endast $200 \mathrm{kr}$., i ett $200 \mathrm{kr}$. af en trikåstickerska, hvars man, en för tillfället arbetslös grofarbetare, har $700 \mathrm{kr}$. inkomst, i de öfriga 50 à $\mathrm{IOO} \mathrm{kr}$.) eller obetydligt öfver I \% af den samlade inkomsten, till beloppet preciserad barninkomst åtnjöts i endast I fall (en I4-årig springgosse med $260 \mathrm{kr}$. årsinkomst, hvars fader var pitpropsarbetare med $600 \mathrm{kr}$. årsinkomst och 7 barn, för tillfället utan anställning). Fattigunderstöd för gamla föräldrar åtnjöts i 2 fall (96 resp. $72 \mathrm{kr}$.). En hustru uppges dessutom ha idkat handelsrörelse; i några få fall sägas barnen ha haft inkomst af tidningsförsäljning; i några omtalas fattigunderstöd till bröd, strumpor och skor eller tofflor. Det kan i detta sammanhang förtjäna nämnas, att för stockholmsundersökningens samtliga I 50 hushåll inkomst af inackordering och uthyrning utgör $4,2 \%$ af samtliga inkomster, hustruns inkomster $2,7 \%$, barns inkomster $2,6 \%$, understöd och gåfvor $0,9 \%$.

Är inkomsten oförändrad, så befinnas medelhyran och -hyres- 
procenten $\mathrm{i}$ stort sedt sjunka med stigande barnantal - om de två högsta, till antalet mycket smả, barngrupperna sammanslås till en; de enda påtagliga afvikelserna förete de två högsta inkomstgruppernas 3 -barnsfamiljer, som betala högre medelhyra än resp. grupps 2-barnsfamiljer. Med oförändradt barnantal och stigande inkomst stiger medelhyran, men hyresprocenten sjunker, d. v. s. andra delar af utgiftsbudgeten svälla starkare än hyran. Hyresprocentens och medelhyrans sjunkande med stigande barnantal torde kunna förklaras med födans ökade kraf. Ett närmare studium af siffrorna erbjuder emellertid ej så litet af intresse.

Går man ut ifrån, att hvarje inkomstgrupp i stort sedt representerar ett socialt skikt, och att de olika barngrupperna äro olika utvecklingsskeden inom samma skikt, skulle tolkningen bli den, att åtminstone de tre lägsta socialgrupperna, under $\mathrm{r}, 300 \mathrm{kr}$. inkomst, redan med andra barnet (i ej ringa utsträckning kanske t. o. m. redan med det första) för bostaden utnyttjat sina ekonomiska resurser till det yttersta, hvadan hvarje sedan tillkommande barn med dess nya anspråk på föda betyder en bostadsinknappning, en om ganska betänkliga förhållanden vittnande tolkning, som i hvarje fall skulle betyda, att äfven en bättre situerad småfolksfamilj $i$ Göteborg icke kan hälla sin bostadsstandard uppe med 4 barn eller däröfver. $\AA$ andra sidan är det klart, att de mycket godtyckligt bildade inkomstgrupperna icke äro att helt och hållet betrakta såsom fixa socialgrupper utan inbördes omsättning. De förhålla sig för öfrigt $\mathrm{i}$ detta afseende något olika. Jag har sökt belysa denna fråga på hvarjehanda sätt. Så har jag, i tabellen sidd. I 26/127, för samtliga 25 inkomst- och barngrupper uträknat dels mannens medelålder, dels barnens procentiska fördelning på åldersgrupperna o/5, 5/10 och 10/1 5 år. Att mannens medelålder såväl som barnens $\mathrm{i}$ stort sedt stiger med växande barnantal, så väl öfver hufvud som för hvarje särskild inkomstgrupp, faller af sig själft. Jämföras åter de olika inkomstgrupperna, oafsedt barnantalet, så befinnes medelåldern oafbrutet stiga från den andra till den femte gruppen: mannens medelålder är 34,75 år, 35,64 år, 35,94 år och 36,99 år; däremot utgör den lägsta inkomstgruppen tydligen en grupp för sig (grofarbetare utan fast anställning); mannens medelålder är här 36,78 år. Då detta inbördes förhållande i stort sedt återkommer för hvarje särskild barngrupp, torde man ha rätt 
att tyda det så, att inkomstutvecklingen .inom de fyra högsta inkomstgrupperna, I,000 kr. och däröfver, i någon mån rör sig uppåt med stigande ålder. - Till någon ringa grad kunna visserligen mannens åldersdifferenser för olika inkomstgrupper tänkas stå i samband med olika giftermålsålder, något stigande med stigande socialstandard. Säkert är, att de högre socialgrupperna ha färre barn än de lägre; antalet barn pr Ioo hushåll är för de fem inkomstgrupperna $345,323,3$ I9, 3 I 3 resp. 315. Den påpekade beklagliga nedgången af medelhyran med stigande barnantal skulle, om man kunde följa samma familjers bostadsutveckling, sålunda möjligen te sig något mindre utpräglad.

$\AA$ bostadskorten begärdes uppgift om datum för inflyttningen till den nuvarande lägenheten samt till näst föregående lägenhet, om hvar denna var belägen, huru många rum den innehöll, huru stor hyran var vid inflyttningen och vid utflyttningen och huru stor vid inflyttningen till den nuvarande lägenheten, samt om huru stor familjen var vid utflyttningen från den förra lägenheten, och om där fanns inhyrande. Alla dessa data ha på ett eller annat sätt utnyttjats vid förevarande undersökning. Antalet rum i den förra lägenheten har sammanräknats - hvarvid inneboende eller kvarboende i hemmet räknats som I rum - för hvar och en af de 25 grupperna och jämförts med motsvarande summa för den nuvarande lägenheten. Medeltalet rum pr lägenhet befanns för samtliga 767 hushåll vara 2,ri mot 2,o5 på det förra stället, alltså 3,2\% flere rum, en onekligen mycket obetydlig ökning för enbart växande familjer. Af de fem inkomstgrupperna uppvisar egentligen endast den högsta en påfallande afvikelse från detta tal, 8,5\%. Men denna afvikelse faller hufvudsakligen på 2- och 3 -barnsgrupperna, där den öfverstiger Io \%. Bortskiljas emellertid de familjefäder, som inflyttat $i$ sin nuvarande lägenhet direkt ifrån hemmet eller en ungkarlslägenhet, blir tillväxtprocenten ej fullt $4 \%$. För att kunna göra sig en någorlunda exakt föreställning om en flyttning betyder tillbakagående eller uppåtgående bostadsstandard, borde man emellertid rätteligen också ha utskilt hushåll, som vid utflyttningen hade inhyrande, helst också sådana som kommo från annan ort, kanske från landet, med helt andra hyresförhållanden. Hvad familjens storlek beträffar, är det naturligtvis också riktigare att utgå från ställningen vid själfva omflyttningstillfället. Det är vis- 
serligen sant, att man icke vet inkomstens storlek vid den tiden. Däremot vet man, såsom ofvan omnämnts, i ett stort antal fall hyrans storlek både vid inflyttningen till det nya och vid utflyttningen från det gamla stället. För ett mindre antal hushåll, för hvilka alla dessa uppgifter förelegat och de nämnda utskiljandena ägt rum, inalles 360 , hạr jag sammanräknat hyran dels vid utflyttningen från den förra lägenheten och dels vid inflyttningen till den nuvarande. Den senare visade sig öfverstiga den förra med $3,7 \%$, alltså en ganska god öfverensstämmelse med rumsökningstalet för de 767 hushållen, allra helst om man räknar med någon allmän hyresförhöjning. För de olika barngrupperna som helheter betraktade, här 4 , o/I barn, 2 resp. 3 samt 4 och flere barn, har icke någon bestämd tendens till hyresstegring resp. nedgång (med växande barnantal) kunnat konstateras, så mycket mera däremot för olika hyresgrupper. Jag har uppdelat de 360 hushållen i 3 hyresgrupper, under I $5 \mathrm{kr}$., I5/20 kr. resp. $20 \mathrm{kr}$. och däröfver pr månad ( I I I resp. I 86 och 63 hushåll). För dessa tre grupper äro de mot IO3,7 \% svarande procenttalen II $4 \%$, I03,5\% och 94,$6 ; \%$; d. v. s. för genomsnittslägenheterna någon obetydlig, för de små, billiga något större utökning och fördyring, för de stora, dyra t. o. m. någon minskning och hyresnedgång. I den största hyresgruppen, genomsnittshyresgruppen, äro procenttalen för de fyra barngrupperna (o/I t. o. m. 4 och flere barn) I06,5\%, I03,8\%, I03,3\% och $97,2 \%$, d. v. s. tydlig lägenhetsutökning för de yngsta, minsta familjerna, sedan högst obetydlig (i synnerhet om man räknar med någon allmän hyresstegring), och till slut inknappning för de största familjerna, fr. o. m. fjärde barnet. I de båda öfriga hyresgrupperna kan ingen bestämd tendens utletas ur procenttalen, möjligen redan af den grund, att de absoluta talen äro för små. De tre hyresgrupperna torde emellertid ännu mindre än de fem inkomstgrupperna få utan vidare uppfattas som verkliga socialstandardgrupper. Därtill äro hyresväxlingarna i många fall alltför skarpa, hyresprocenterna alltför variabla. Öfver hufvud får man af ett närmare studium af bostadskorten ett lifligt intryck af det inflytande bristande förutseende utöfvar på hyresbildningen. Då större delen af de här behandlade hushållen befinna sig helt nära existensminimigränsen, är det gifvet, att minsta rubbning af deras allmänna läge, vare sig beträffande inkomsten eller familjens storlek, skall 
göra sig kännbar i fråga om hyran. Minsta öfverskridande af den tillrådliga hyresprocenten hämnar sig genast genom nödtvungen afflyttning till billigare lägenhet. Men flyttning framkallas också af en mängd andra faktorer. De täta flyttningarna bli därför också ett karakteristiskt drag i småfolkshushållens bostadsutveckling. En undersökning af boendetiden, tiden från inflyttningen $i$ lägenheten, kan ej utelämnas $\mathrm{i}$ en studie sådan som denna, om också siffrorna äro nog så svårtolkade.

Räknad till undersökningsdagen är medelboendetiden för samtliga 767 hushåll $3 \frac{1}{2}$ år; med stigande barnantal stiger den tydligt, såsom ju också måste väntas, redan af det skäl att den första bosättningsflyttningen spelar en alltjämt aftagande roll med tilltagande familjeålder. Från den andra inkomstgruppen stiger den också oafbrutet till den femte; 3, or år, 3,55 år, 3,72 år och 3,87 år; i den första inkomstgruppen är den 3,29 år. Inom de särskilda inkomstgrupperna tenderar boendetiden att stiga med växande barnantal, likaså inom resp. barngrupp med stigande inkomst. Det senare förhållandet skulle möjligen $i$ någon mån kunna sammanhänga med det förut påpekade, att med stigande inkomst för samma barnantal äfven mannens och barnens medelålder, alltså väl också äktenskapets, stiger något. Att den lägsta inkomstgruppens medelboendetider i stort sedt äro högre än närmast högre grupps motsvarande, skulle alltså bero på, att äktenskapen i den förra äro af äldre datum än $\mathrm{i}$ den senare.

För de 360 hushållen har jag också uträknat medelboendetiden, för alla dess 12 grupper, $\mathrm{i}$ den förra lägenheten. Ehuru vi här ha att göra med en fullt utgången hyresperiod, för de 767 åter med en genom bostadsundersökningen afklippt, få vi i förra fallet ett afsevärdt lägre medeltal, föga öfver 2 år, 2,13. Detta vid första påseende egendomliga förhållande torde $\mathrm{i}$ hufvudsak kunna förklaras på följande sätt. Bland de 767 hushållen äro endast medtagna sådana, där intet hemmavarande barn fyllt i 5 år, d. v. s. i regel med högst 15 års äktenskap, i genomsnitt säkerligen ej med ro års. De 360 utgöra ett urval ur dessa 767 . I den mån deras senare bostadstid varit mycket lång, måste alltsâ deras första bli jämförelsevis kort. För de tre första distrikten blef sålunda den senare medelboendetiden nära tre år $(2,92$ år $)$, den tidigare $2 \frac{1}{2}$ år. Dock har boendetiden $i$ mer än hälften af alla 
fallen, 47 af 92 , sjunkit. Medelboendetiden i den nya lägenheten blir för de 360 hushållen 2,70 år; för deras barngrupper bli medelboendetiderna $\mathrm{i}$ de tidigare lägenheterna $\mathrm{I,45}$ resp. 2,22 och 2,52 år (för $\mathrm{o} / \mathrm{I}, 2$, resp. 3 och flere barn). De tre hyresgrupperna uppvisa också stigande medelboendetid (med stigande hyra) 2,08 resp. 2, ri och 2,25 år. Högre hyra skulle alltså i viss mån liksom högre inkomst under för öfrigt lika förhållanden stå tillsammans med längre bostadstid. I någon ringa mån kunde man emellertid tänka sig, att de olika hyresgruppernas olika medelboendetider sammanhänga med olika ålder vid giftermålet resp. vid bosättningen $\mathrm{i}$ Göteborg. Den förra har uträknats och visat sig vara $27, \mathrm{r} 6$ resp. 27,22 och 27,80 år, alltså något stigande med stigande hyra, hvilka tal man skulle frestas att tolka som särskilda socialstandardindices, om ej liknande beräkningar för inkomstgrupperna gifvit tämligen negativa resultat. Medeltiden från bosättningen (i Göteborg) till inflyttningen till den nuvarande lägenheten har också uträknats för samtliga 12 hyres- och barngrupper. - För samtliga 360 hushåll blef den 5,45 år (giftermålsåldern var 27,3 år, äktenskapsvaraktigheten 5,9o år). - En jämförelse mellan dessa tal och medelboendetalen för den gamla lägenheten ger vid handen, att de senares procentandëlar af de förra med växande barnskara uppvisa en bestämdt aftagande serie (från $55 \%$ för de minsta till $23^{1} / 2 \%$ för de största familjerna), såsom ju också var att vänta, medan däremot motsvarande procenttal för hyresgrupperna icke förete något anmärkningsvärdt. Medelboendetidens förlängning med stigande hyra, för 2-barnsgruppen (den till antalet största familjegruppen), från $\mathrm{I}, 95$ till 2,30 resp. 2,43 år, torde alltså få tydas såsom stående $\mathrm{i}$ samband med stigande socialstandard. En uppdelning af de 360 hushållsföreståndarne efter stigande ålder har gifvit till resultat, att inkomsten når sin högsta höjd redan före fyllda 40 år ( 35 år).

En särskild liten specialundersökning har utförts öfver hushåll, som vid inflyttningen till den nya lägenheten betalat minst IO \% lägre hyra än vid utflyttningen från den gamla, omfattande inalles 60 hushåll af de 360 , däraf $\mathrm{i}$ resp. hyresgrupper 7,22 och 3 I eller $6,3 \%$, I I $8 \%$ och $49,2 \%$. För o/I, $2 / 3$ och 4 och flerbarnsgrupperna äro motsvarande procenttal I $2,3 \%$, I7 \% och $22 \%$. Att en väsentligare hyresminskning knappast ens är tänkbar från redan förut mycket låga hyror, för ett enda litet rum 
t. ex., säger sig själft. Snarare får då fattigunderstöd tillgripas. Att det är de större familjerna, som, när det öfver hufvud är möjligt, träffas af hyresminskning, är också tydligt. Hvad som vid studiet af de 60 korten genast faller i ögonen är eljest den genomgående korta boendetiden $\mathrm{i}$ den gamla lägenheten. Medelboendetiden är sålunda endast $I_{, 74}$ år, trots de relativt många stora familjerna, om hushåll med $\mathrm{O} / \mathrm{I}$ barn frånräknas I,87 år. 35 af de 60 hushållen ha bott högst $\mathrm{I}$ år $\mathrm{i}$ den gamla lägenheten, Io ej fullt $\mathrm{I}$ år. Endast i 23 har boendetiden i den nya lägenheten hittills varit kortare. I den högsta hyresgruppen, minst 20 kr. pr månad, uppgår medelboendetiden på gamla stället för de 3 I hushållen med minst io \% hyresminskning vid flyttningen ej till $\mathrm{I}^{3} / 4$ år mot mer än $23 / 4 \mathrm{i}$ denna grupps öfriga 32 hushåll; medelboendetiden $\mathrm{i}$ den nuvarande lägenheten är 2,14 år resp. 2,60 år, den nuvarande medelinkomsten I,479 kr. resp. I,859 kr., hyresprocenten $13 \%$ resp. I $4,2 \%$. I 2 I af de 60 fallen anföres för hög hyra som orsak till flyttningen. I ej så få fall är hyresprocenten förvånande låg. Uppgifter om hyrans storlek före inflyttningen till näst föregående lägenhet ge vid handen, att den ofta då ökats ungefär lika mycket som den vid utflyttningen minskats. Här anförda tal och omständigheter befästa det allmänna intrycket af den roll bristande ekonomiskt förutseende spelar i hyresfluktuationen och som fått ett skarpt uttryck i de täta omflyttningarna.

Man kan gå ut ifrån, att hushåll med mycket höga hyresprocenter i stor utsträckning tillhöra samma grupp som de 60 , ehuru i deras tidigare skede, strax före inflyttningen till den nuvarande lägenheten. Så karakteriseras de af mycket korta boendetider. Hela antalet göteborgshushåll, hvilka på grund af att hyresprocenten uppgått till minst $25 \%$ uteslutits ur undersökningen, utgör 64, hela antalet hushåll, som uteslutits på grund af att inkomsten ej uppgifvits (eller uppgiften alldeles tydligt varit ofullständig), till I I8. Sammanläggas dessa tal med 767, får man 949. Häraf utgöra 64 och I I $8,7 \%$ resp. I $2,4 \%$. Sammanläggas 64 och 767 , får man $83 \mathrm{I}$, hvaraf 64 utgör $7,7 \%$. Till jämförelse skall nämnas, att i Vänersborg hushåll utan taxerad eller med obekant inkomst " utgjorde 40,i \% af samtliga hushåll utan andrahandshyrande, och att antalet hushåll med minst $25 \%$ 
hyresprocent (af lägenhetsinnehafvarens inkomst) utgör I 3,5\% af hela antalet med känd inkomst. Af de 64 med minst $25 \%$ hyresprocent tillhöra ej mindre än 44 den lägsta inkomstgruppen, under I,O0O kr. inkomst. Af de 44 tillhöra endast 5 I \% 2- och 3-barnsgrupperna mot 6 I \% af de 158 (med under $25 \%$ hyresprocent); $39 \%$ resp. $30 \%$ ha bebott sin nuvarande lägenhet mindre än I år (för 2- och 3-barnsgruppen är skillnaden ändå större). Af de 60 hushållen med minst 1o \% hyresminskning ha 22 eller $37 \%$ bott mindre än I år i den nuvarande lägenheten, $58 \%$ ha bott högst I år på gamla stället mot $50 \%$ af de 44 (med minst $25 \%$ hyresprocent). Sammanslås de 44 med de 158 , blir medelhyresprocenten för hela den lägsta inkomstgruppen - sedan en del korrigeringar af inkomstuppgifterna verkställts med taxeringslängdernas tillhjälp - 20,5 \%; sammanslås de 64 med de 767 , får man i $7 \%$ - i stället för $19,2 \%$ resp. I6,4 \%. Medelinkomsten för de $83 \mathrm{I}$ hushållen blir I,279 kr. (i stället för I,299 kr. för de 767), årshyran 2 I 7 kr. (i stället för $2 \mathrm{I} 3 \mathrm{kr}$.). För de 202 hushållen med under $\mathrm{I}, 000$ $\mathrm{kr}$. inkomst blir medelinkomsten $856 \mathrm{kr}$. (i stället för $872 \mathrm{kr}$.), medelhyran $175 \mathrm{kr}$. (i stället för $\mathrm{I} 67 \mathrm{kr}$.).

Årshyran har också uträknats pr rum, och visar det sig, att rumshyran i stort sedt stiger med stigande inkomst och sjunker med stigande barnantal. För de fem inkomstgrupperna är den $83,85 \mathrm{kr}$., 95,94 kr., IOO,36 kr., IO2,9I kr. och I I 8,40 kr. mot IOO,79 $\mathrm{kr}$. för samtliga 767 lägenheter, för de fem barngrupperna I 3,62 kr., 102,18 kr., 98,04 kr., 96,04 kr. och 93,03 kr. Liknande tendens kan spåras, om man kombinerar de båda indelningsgrunderna. Vidare har luftrymden uträknats såväl pr lägenhet som pr rum och pr personenhet, hvarvid barn räknats som half personenhet, årshyran därjämte pr kubikmeter luftrymd. Årshyran pr kubikmeter stiger med växande inkomst; för de fem inkomstgrupperna är den 2,21 kr., 2,28 kr., 2,30 kr., 2,30 kr. och 2,33 kr. mot 2,29 kr. för samtliga lägenheter, och sjunker med stigande barnantal; för de fem barngrupperna är den 2,33 kr., 2,29 kr., 2,28 kr., $2,13 \mathrm{kr}$. och $2,22 \mathrm{kr}$. Medelluftrymden $\mathrm{pr}$ lägenhet ökas med stigande inkomst i svagare tempo än medelhyran; dess aftagande med stigande barnantal är knappast påvisbart, sannolikt närmast beroende på att de barnrika familjerna söka sig ut mot stadsperiferien med dess billigare hyror. För de fem inkomstgrupperna 
äro luftrymdsmedeltalen $74,44 \mathrm{~m}^{3}, 85,49 \mathrm{~m}^{3}, 89,08 \mathrm{~m} .^{3}, 9^{2,70 ~ m .{ }^{3}}$ och I 24,68 m. ${ }^{3}$ mot $92,95 \mathrm{~m}^{8}$ för samtliga lägenheter, för de fem barngrupperna $93,63 \mathrm{~m} .^{8}, 95,78 \mathrm{~m}^{3}, 89,48 \mathrm{~m}^{3},{ }^{3}, 92,73 \mathrm{~m} .^{8}$ och $86,3^{8} \mathrm{~m} .{ }^{3}$ Tilläggas de 64 hushållen med minst $25 \%$ hyresprocent, blir luftrymdsmedeltalet för samtliga 831 lägenheter $93,03 \mathrm{~m} .^{3}$; för de 202 med under $\mathrm{I}, 000 \mathrm{kr}$. inkomst blir det $76,74 \mathrm{~m} \cdot{ }^{3}$ Rummens storlek växer också med stigande inkomst, medan däremot vare sig minskning eller ökning med stigande barnantal kan konstateras. Att luftrymden pr personenhet skulle stiga med stigande inkomst och aftaga med stigande barnantal faller af sig själft. Då jag anser det sätt, på hvilket personenheten bildats, vara ganska godtyckligt - om ock det vanligaste och kanske för gröfre undersökningsmetoder mest praktiska - inskränker jag mig här till att hänvisa till tabellen under framhållande af, att I $5 \mathrm{~m}^{3}$ oftast plägar sättas som "hygieniskt minimum», i samband hvarmed må nämnas, att procenttalen lägenheter med under I $5 \mathrm{~m}^{3}$ pr personenhet för de fyra lägsta inkomstgrupperna äro $20,3 \%, 8 \%, 6,3 \%$ och $2,3 \%$, för samtliga lägenheter $7,4 \%$. Hela antalet i de 767 lägenheterna boende utom föräldrar och barn uppgår till $5^{2}$ eller 7 personer pr Ioo lägenheter (en på hvarje $15: d e$ ), mest far- och morföräldrar samt tjänare. De två högsta inkomstgrupperna ha något flere "öfriga boende" (mest tjänare), 7 resp. I6 $\mathrm{pr}$ IOO hushåll mot endast $4 \mathrm{i}$ de tre lägsta.

I öfrigt hänvisas i detta sammanhang till min uppsats, 1907 års bostadsundersökning $i$ Upsala (i Upsala Läkareförenings förhandlingar, N. F., Bd XVI), där jag för 737 »normalhushåll» ur småfolksklassen $\mathrm{i}$ Uppsala utfört en hyresprocentundersökning något liknande den göteborgska. I uppsalaundersökningen ha endast medtagits gifta män med minst $600 \mathrm{kr}$. inkomst - de som haft lägre inkomster ha ansetts som "icke skötsamma» - hvilkas hustrur och barn endast obetydligt bidragit till familjens underhåll. Äfven barnlösa och I-barnsäktenskap ha medtagits, och familjer med äldre barn ha ej utskilts. Det kan förtjäna påpekas, att inkomstuppgifterna för uppsalamaterialet genomgående äro sämre, mindre specificerade, än för göteborgsmaterialet. Afskiljas o- och I-barnsfamiljerna, få vi 389 uppsalafamiljer med en medelinkomst om $949 \mathrm{kr}$. (mot I,279 för samtliga de 83 I göteborgsfamiljerna), en medelårshyra om $147 \mathrm{kr}$. (mot $2 \mathrm{I} 7 \mathrm{kr}$.), en medel- 
hyresprocent om I5,6\% (mot i $7 \%$ ) och en medelluftrymd om $64 \mathrm{~m}^{3}$ (mot $94 \mathrm{~m}^{3}{ }^{3}$ ). För inkomstgruppen under $\mathrm{r}, \mathrm{OOO} \mathrm{kr}$. bli motsvarande tal $820 \mathrm{kr}$. (och $856 \mathrm{kr}$.), I $39 \mathrm{kr}$. (och I75 kr.), I $7 \%$ (och 20,5\%) samt 6I m. ${ }^{3}$ (och $77 \mathrm{~m}^{3}{ }^{3}$ ), för 235 och 202 fall. Medelinkomsten utgör i Uppsala för 2-, 3-, 4- resp. 5- och flerbarnsgrupperna $923 \mathrm{kr}$., $960 \mathrm{kr}$., I,007 kr. resp. 95 I kr., medelhyran I $44 \mathrm{kr}$., I 5 I kr., I $54 \mathrm{kr}$. resp. I $45 \mathrm{kr}$., medelhyresprocenten $\mathrm{I}_{5,9} \% \mathrm{I}_{5}, 9 \%$, I $5,8 \%$ och $\mathrm{I}_{5}, 6 \%$, medelluftrymden pr lägenhet $60 \mathrm{~m}^{3}, 65 \mathrm{~m}^{3}, 70 \mathrm{~m}^{3}{ }^{3}$ och $70 \mathrm{~m}^{3}$ För O- och I-barnsfamiljerna äro motsvarande tal 908 resp. $927 \mathrm{kr}$., I 44 resp. I $48 \mathrm{kr}$., I6,4\% resp. I $6,5 \%$ samt 47 resp. $6 \mathrm{I} \mathrm{m}^{3}$, för samtliga 737 hushåll $935^{1}$ kr., I $47 \mathrm{kr}$, , I6, г \% samt $62 \mathrm{~m}^{3}$ Antalet hushåll med minst $25 \%$ hyresprocent utgör för de 389 hushållen med 2 och flera barn endast 20 eller 5, г \% (mot 7,7\% för de 83 I göteborgska), för samtliga $7376,2 \%$.

Till slut några siffror till jämförelse mellan de 767 göteborgsfamiljerna och samtliga 5, I I 5 år I 9 I I undersökta (se för öfrigt själfva berättelsen, De mindre bemedlades bostadsförhållanden $i$ Göteborg, tryckt I9I 2 hos Wald. Zachrissons boktryckeri tillsammans med den samtidiga bostadsräkningen). Medelårshyran är i förra fallet $2 \mathrm{I} 3 \mathrm{kr}$., i det senare $22 \mathrm{I} \mathrm{kr}$., pr kubikmeter 2,29 resp. $2,47 \mathrm{kr}$., medelluftrymden pr lägenhet $93 \mathrm{~m}^{3}$ resp. $89 \mathrm{~m}^{3}$, pr rum 44 resp. $42 \mathrm{~m}^{3}$, pr personenhet $25,{ }^{2} \mathrm{~m}^{3}{ }^{3}$ resp. $27,3 \mathrm{~m}^{3}$, antalet boende pr lägenhet 5,30 resp. 3,95, pr rum 2,59 resp. I,86, antalet rum pr lägenhet $2, \mathrm{Ir}$ resp. 2,12, medelboendetiden $3 \frac{1}{2}$ år resp. $23 / 4$ år. Mannens medelålder är 36 resp. 46 år för enbart gifta män, inalles 3,279, 43 år, en åldersskillnad som naturligen beror på själfva urvalsprincipen för den mindre gruppen. Observeras må särskildt, att trerumskategorien, som $i$ stor utsträckning torde innehas af hushåll med vuxna barn, är relativt svagt representerad bland de 767 lägenheterna.

${ }^{1}$ Härmed rättas ett tryckfel i uppsatsen (där medelinkomsten uppges vara $95 \mathrm{I}$ kr.) 